\title{
REDUCTION OF NOUN CLASS SUFFIXES IN AKEBU
}

\author{
Andrey Shluinsky \\ Institute of Linguistics RAS \\ ashl@yandex.ru
}

Abstract: This paper presents a pilot instrumental study of phonetic reduction of noun class suffixes in Akebu (Kwa, Ghana-Togo mountain, West Africa). Noun class suffixes starting with a glide are regularly perceived as omitted or almost omitted, and therefore full and reduced variants can be distinguished for such nouns. A formant measurement of final parts of full and reduced forms of the same nouns has shown that, first, for a given final part of a noun stem the reduced variant is phonetically close to the corresponding full variant and, second, for a given final part of a noun stem the forms with reduction of different suffixes are phonetically different.

Key words: noun class marking, phonetic reduction, formant measurement, Akebu, Kwa

\section{Introduction}

\subsection{Language background and data}

This working paper is a pilot study of phonetic reduction of noun class suffixes in Akebu.

Akebu (Kebu; ISO 639-3 keu) is a Kwa language of the KebuAnimere $^{1}$ group. It is spoken mainly in the prefecture of Akebu in Togo (West Africa) by ca. 70000 people (Gblem-Poidi \& Kantchoa 2012; Eberhard et al. (eds.) 2019). The language is underdescribed, although a number of references exist. I mention here existing work on phonology and noun classes, since this study lies at the intersection of these two

${ }^{1}$ Kebu-Animere group is as a part of a unity referred to as "Ghana-Togo Mountain languages", or "Togo Remnant languages". 
areas. Wolf (1907) published a brief grammar sketch. Some aspects of both the phonology and noun class system of Akebu are briefly discussed by Heine (1968: 70-73, 110, 126, 182-184). Djitovi (2003) and Jacques Sossoukpe (2017) made preliminary descriptions of phonology. Storch \& Koffi (2000) and Amoua (2011) describe noun systems and noun classes. M'boma (2012) and Marthe Sossoukpe (2014) invented and proposed writing systems, addressing the phonological system in this way, as well. Makeeva $(2013 ; 2016)$ described the Akebu phonological system in more detail and made some clarifications. Makeeva \& Shluinsky $(2015 ; 2018)$ described the noun class system.

The phenomenon addressed in this paper has never been in focus of a separate study, and no published results of instrumental studies of any aspects of the Akebu sound system exist so far. This research has been performed on a very limited amount of data, and I recognize that the issue should be further studied in a more precise way. Still, this study makes it possible to make a descriptive decision for further work with Akebu data and should therefore be presented. Importantly, this paper does not deal with Akebu noun class system in general and provides only a brief summary; more details can be found in (Makeeva \& Shluinsky 2018).

This research is a part of a long-term study of Akebu that has included a number of field trips to the village of Djon and neighbouring villages of Kotora and Djitrame in the prefecture of Akebu of Togo in 2012, 2013, 2016 and 2019. While the general background of Akebu linguistic structure comes from all these fieldtrips and is based both on elicited examples obtained from several consultants and on natural texts recorded from dozens of speakers, the data for the study in focus were elicited from a single speaker in 2016.

\subsection{Vowel system and the tone-bearing nasal}

Akebu has a rather typical Kwa vowel and consonant phoneme inventory and a tonal system of three level tones that is described 
in (Makeeva 2016). Only phenomena relevant for this study are addressed here.

\section{Table 1}

Vowel system of Akebu

\begin{tabular}{|c|c|c|}
\hline $\mathrm{i}$ & $\mathrm{i}$ & $\mathrm{u}$ \\
\hline $\mathrm{I}$ & & $\mho$ \\
\hline $\mathrm{e}$ & $\partial$ & $\mathrm{o}$ \\
\hline$\varepsilon$ & & 0 \\
\hline & $\mathrm{a}$ & \\
\hline
\end{tabular}

Table 1 presents the vowel system of Akebu, which contains 11 vowels. Root vowel harmony makes it possible to distinguish three sets, and vowels from different sets cannot coexist in the same root: phonologically +ATR non-central $(i, u, e, o)$, phonologically -ATR ( $I$, $U, \varepsilon, \partial)^{2}$ and, what is untypical for Kwa, +ATR central $(\dot{i}, \partial)$. The vowel $a$ is neutral and can be attested with the vowels of any set.

Phonetically, long vowels are also present in Akebu, e.g. $a a, \varepsilon \varepsilon$ etc. Phonologically, they are analyzed here as double vowels (i.e. sequences of two identical vowels), since they can bear contour tones (e.g. àá, áà), while there are no phonological contour tones in Akebu attested with short/single vowels. ${ }^{3}$

The nasal segment $\eta$ has two different realizations. When it is syllable-initial (e.g. yúáá-tá 'door'), it behaves as a standard consonant, bears no tone and triggers progressive allophonic vowel nazalization, like other nasals. When syllable-final (e.g. góǹ- $t \bar{\partial}$ 'way') or independent, it bears its own tone, and is regressively assimilated by the subsequent

${ }^{2}$ The question of whether phonetically +ATR $(i, u)$ vs. -ATR $(I, U)$ and close $(e, o)$ vs. open $(\varepsilon, \jmath)$ oppositions have common acoustic correlates remains open for Akebu.

${ }^{3}$ As an anonymous reviewer pointed out, alternatively one can analyze the mora as the tone-bearing unit, and therefore accept long vowels as two-moraic phonological units. 
consonant (since this assimilation is allophonic, this is not marked in the transcription), triggers regressive vowel nazalization, but can still usually be segmented.

Glides $w$ and $y$ (IPA [j]) have the standard consonant distribution.

\subsection{Noun class system}

The noun class system of Akebu is described in detail in (Makeeva \& Shluinsky 2018). In Akebu, noun classes are expressed by a combination of the residual Proto-Kwa noun class marking by prefixes and of the newly developed noun class marking by suffixes that is not typical for Kwa (see Konoshenko \& Shavarina 2019 for a survey).

Table 2

Noun classes of Akebu: markers and examples

\begin{tabular}{|c|c|c|c|}
\hline class & prefix & suffix & examples \\
\hline $\mathrm{D} \sigma$ & $\varnothing-$ & $-y \bar{\partial}$ & fūtí-yá 'bird' \\
\hline РӘ & $\grave{V}-{ }^{4}$ & $-p \bar{\partial}$ & $\begin{array}{l}\text { à-pj̄̄̄-pā 'oil' } \\
\text { ò-fūtí-pá 'birds' }\end{array}$ \\
\hline ТӘ & $\varnothing$ - (voicing) & $-t \bar{\partial}$ & gò-t’̄ 'liver' \\
\hline Wə & $\varnothing-$ & $-w \bar{\partial}$ & náá-wá 'fire' \\
\hline YӘ & $\grave{V}-$ & $-y \bar{\partial}$ & $\begin{array}{l}\text { à-kpù-yā 'bag', } \\
\text { à-náá-yá 'fires' }\end{array}$ \\
\hline \multirow[t]{3}{*}{$\mathrm{K} \partial$} & $\emptyset$ - (voicing) & \multirow[t]{3}{*}{$-k \bar{\partial}$} & gà-kā 'meat' \\
\hline & $\grave{V}-$ & & $\grave{a}-k \bar{a} \bar{a}-k \bar{\partial}$ 'hand' \\
\hline & k̀̀- & & kà-tōō-kā 'feather' \\
\hline \multirow[t]{2}{*}{ КРӘ } & wà- & \multirow[t]{2}{*}{$-k p \bar{\partial}$} & $\begin{array}{l}w \grave{\partial}-t a ̀ a ̀-k p \bar{a} \text { 'market' } \\
w \grave{\partial}-t \bar{o} \bar{o}-k p \bar{\partial} \text { 'feathers' }\end{array}$ \\
\hline & $\varnothing-$ (voicing) & & gú-kpá 'room' \\
\hline
\end{tabular}

4 This symbol refers to an underspecified vowel subject to regressive vowel harmony (see Makeeva \& Shluinsky 2018 for details). 
Table 2 (reproduced from Makeeva \& Shluinsky 2018: 5) introduces the list of the seven Akebu noun classes, their marking by prefixes and suffixes and their labeling by the form of the object pronouns. The $\mathrm{D \mho}, \mathrm{T}, \mathrm{W}$ a and $\mathrm{K} Ә$ classes can refer only to single objects, and the $\mathrm{P}$, YӘ and КРӘ classes can either refer only to singular objects or contain plural forms.

As seen in the examples in Table 2, noun class suffixes bear a high tone after a high tone and a mid tone otherwise.

Being residual and presumably ascending to a proto-language, noun class prefixes are morphologically stable and can never be omitted. But for the noun class suffixes there are rare syntactic contexts where they can be optionally omitted. One of such contexts is the position of the head noun of an NP containing a wh-word, as in (1)-(2). Both (1a) and (2a) where the nouns contain a class suffix and (1b) and (2b) without the suffix are acceptable. It is worth noting that this omission of the class suffix driven by a syntactic context is possible with every noun class, and (1) and (2) exemplify the nouns $k \grave{\partial}-f \bar{c} \bar{\varepsilon} \bar{\varepsilon}-k \bar{\partial}$ 'book' and nàtā-wā 'house' of the noun classes $\mathrm{K} Ә$ and $\mathrm{W} \partial$ that have different shapes of the class suffixes.
(1) a. ̀̀lā lá kà-fū $\bar{c} \bar{\varepsilon}-k \bar{a}$ ? who POSS Кə-paper-Кə 'Whose book (is this)?'
(2) a. ̀̀là lá nàt̄̄-wā ?
who poss house-wə
'Whose house (is this)?'

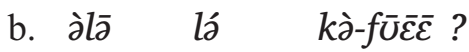
who POSS Kə-paper
b. àlā lá nàtā ?
who poss house

\subsection{The phenomenon of noun class suffix reduction}

There are many other instances of nouns where a class suffix, at least at first glance, is not present in the speech or is weakly heard. For example, a rough phonetic transcription of the underlined nouns in the sentence (3) taken from a natural text is [cíkèć] and [púúsùī]. 


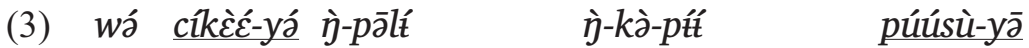

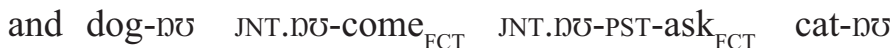 'And the dog asked the cat ...'}

The phenomenon of noun class suffix reduction presented in (3) is completely different from the phenomenon of noun class suffix omission presented in (1)-(2). First, the phenomenon of noun class suffix reduction is not driven by syntactic context and virtually is possible in any position. Second, only suffixes of the $\mathrm{D \mho}, \mathrm{Y} \partial$ and $\mathrm{W} Ә$ classes are subject to reduction, and this is evidently related to their phonological shape: two of them take the suffix $-y \bar{\partial}$, and one of them takes the suffix $-w \bar{z}$, the two being the only noun class suffixes starting with a glide. Third, as mentioned, the noun class reduction is not always perceived as complete absence of the marker, in contrast to the noun class omission.

The phenomenon of noun class reduction is not driven by speech register or genre and is consciously recognized by speakers who differentiate between a "long" (i.e. full) and a "short" (i.e. reduced) variants of the same noun, on the one hand, but say that a "long" and a "short" variants of the same form are "the same", on the other.

According to researcher's audial impressions, a noun class suffix may be reduced to a zero, to one segment or make a coarticulated form with a preceding segment, but this depends on the final part of the noun stem. The reduced variant is perceived in different ways, depending on the single vowel (V), double vowel (VV) and vowel followed by a tone-bearing nasal $(\mathrm{Vy})$ shape of the final part and, also on the vowel quality.

Using a very conventional transcription ${ }^{5}$, one can give the following preliminary rules for the reduced variants.

${ }^{5}$ In this convetional transcription, I do not mark the tone of the final segment, since what occurs with the tone of the class suffix in a reduced form requires a separate study. 
With the suffix $-y \bar{\partial}, V-y \bar{\partial}$ gives [VV] (i.e. the final vowel of the final part is lengthened) with front and middle vowels (e.g. $\grave{e}$-cì-yā [ècìi] 'days', $\grave{a}-l \bar{\varepsilon}-y \bar{\partial}$ [àl $\bar{\varepsilon} \varepsilon]$ 'bellies') and [Vi] / [VI] (i.e. the final vowel of the final part is followed by a close front vowel) with back vowels (e.g. ò-tù-yā [òtùi 'things', à-tùkū-yā [à-tòkūi] 'knives'). $V V-y \bar{\partial}$ gives [VV] (i.e. the suffix is perceived to be reduced to zero) after double

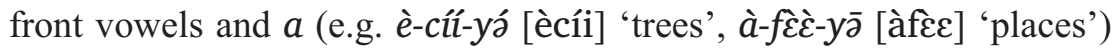
and [Vi] / [VI] (i.e. one of the identical final vowels of the final part is replaced by a close front vowel) with back vowels (e.g. ò-kóó-yá [òkói] 'fruit stems, umbilical cords'). $V \eta-y \bar{\partial}$ gives [ṼṼ] (i.e. the final vowel of the final part is lengthened, and the nasal is realized as a nazalization of the vowels) with front vowels except $\varepsilon$ (e.g. è-nín-yá [ènîî] 'tips') and [ $\left[\tilde{V}_{1} 1\right] /\left[\tilde{V}_{I}\right]$ (i.e. one of the identical final vowels of the final part is replaced by a close front vowel, and the nasal is realized as a nazalization of the vowels) with other vowels ( $\grave{o}-f \bar{u} \bar{\eta}-y \bar{\partial}$ [òfũ̃ $]$ 'pits', à-kpàǹ̀-yā [àkpãã] 'bells').

With the suffix $-w \bar{\partial}, V-w \bar{z}$ gives [VV] (i.e. the final vowel of the final part is lengthened) with back vowels (e.g. tù-wā [tùù] 'thing') and $\left[\mathrm{VV}^{\mathrm{w}}\right]$ (i.e. the final vowel of the final part is lengthened and, at least in its last part, labialized) with front and middle vowels (e.g. nìmí-wá [nìmíy] 'needle', sáná-wá [sánáe] 'sheaf'). $V V$-wā gives [VV] (i.e. the suffix is perceived to be reduced to zero) with back vowels and $a$ (e.g. kóó-wá [kóó] 'fruit stem, umbilical cord', náá-wá [náá]

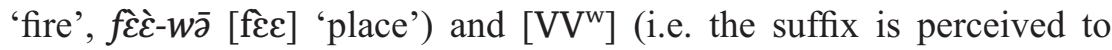
be reduced to zero, but the second vowel of the final part is labialized)

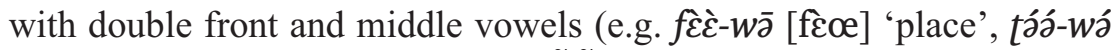
[tə́⿱㇒⿻] part is lengthened, and the nasal is realized as a nazalization of the

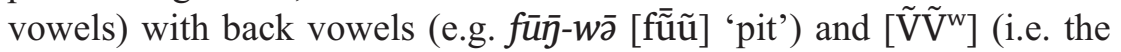
final vowel of the final part is lengthened and, at least in its last part, labialized, and the nasal is realized as a nazalization of the vowels) with other vowels (e.g. nín-wá [nî̃ỹ] 'tip', kpàỳ-wā [kpầõ̃] 'bell').

It is, however, important to note that all these rules are impressionistic, since they are based only on my own perception which is completely 
subjective. ${ }^{6}$ The goal of this paper is therefore to provide an objective piece of evidence on what reduced variants look like phonetically by means of an instrumental study. Although the study is a pilot, it shows, in particular, that a conventional transcription of the reduced variants as given above does not reflect all their acoustic peculiarities.

\section{Design of the formant measurement study}

Since audial impressions of the reduced variants of nouns show that all these forms differ in the quality of the final vowel or vowel sequence, it is evident that vowel formant measurement can be chosen as the main instrument of the study. If one compares vowel formants of the same noun stem in its form without a class suffix (taken from a syntactic context where noun class suffix omission is possible) with its reduced variants with reduction of different class affixes, one can see that all the three forms with an absent or a reduced class affix differ in their formant structure. For example, $(4 \mathrm{a}-\mathrm{c})$ presents the noun 'needle': nìmí-wá (the class $\mathrm{W} \oslash$, singular form) è-nìmí-yá (the class YӘ, plural form). Figure 1a shows a spectrogram of its form nìmí taken from the sentence (4a) where its bare stem with no class suffix is present. On Figures $1 \mathrm{~b}$ and $1 \mathrm{c}$ one can see spectrograms of the reduced variants of its singular (4b) and plural (4c) forms respectively. The vowel formant structure of the last vowel on Figure $1 \mathrm{~b}$ is evidently different from the vowel formant structure of the last vowel on Figures 1a and $1 \mathrm{c}$, showing a significantly lower value of F2 that should be due to a more back articulation.

(4) a. ká lá nìmí wá ōlō-fú ?
what POSS needle FOC 2sG.PFV-buy
'What kind of book have you bought?'

${ }^{6}$ In fact, impressions from spectrograms of some pronunciations were also taken into account. Still, this kind of analysis is impressionistic as well. 


b. nìmí-wá [nìmíy] c. è-nìmí-yá [ènìmíi]
$\begin{aligned} & \text { needle-wə } \\ & \text { 'needle' }\end{aligned}$
$\begin{aligned} & \text { Yə-needle-Yə } \\ & \text { 'needles' }\end{aligned}$

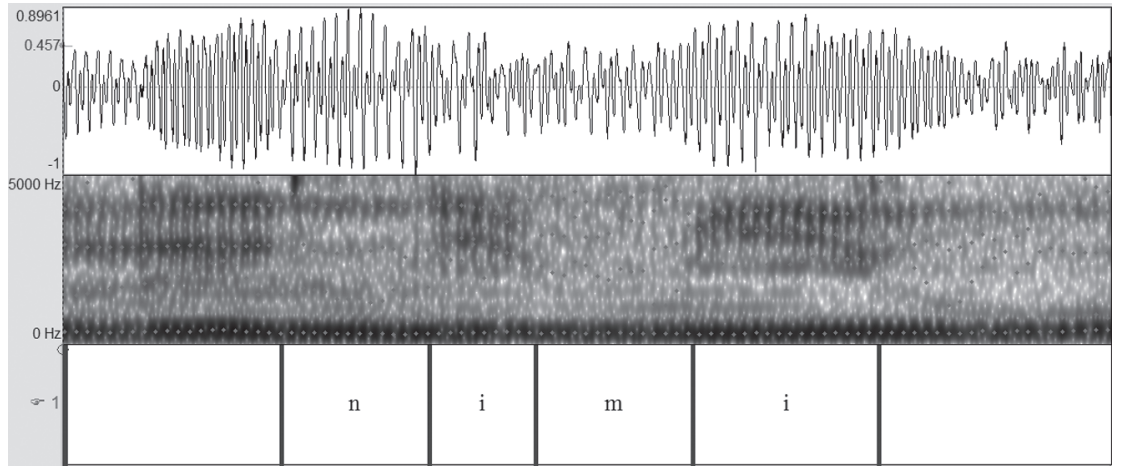

Figure 1a. A spectrogram of the form nìmí from (4a)

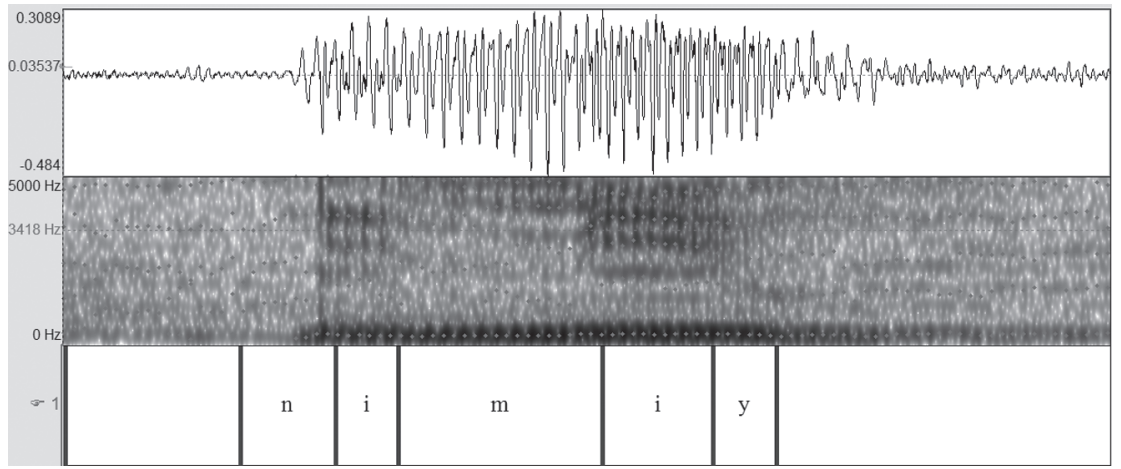

Figure 1b. A spectrogram of the form nìmíwá [nìmíy] from (4b)

Unfortunately, it was not possible to get the form without a class suffix in isolation, without the necessary syntactic context, and nonisolated instances do not always work well for acoustic measurements. This is why I made the decision to compare final parts of the same stems in four types of contexts: full $w \bar{\partial}$-form, reduced $w \bar{\partial}$-form, full $y \bar{\partial}$-form, reduced $y \bar{\partial}$-form. Sometimes this is possible with the same 


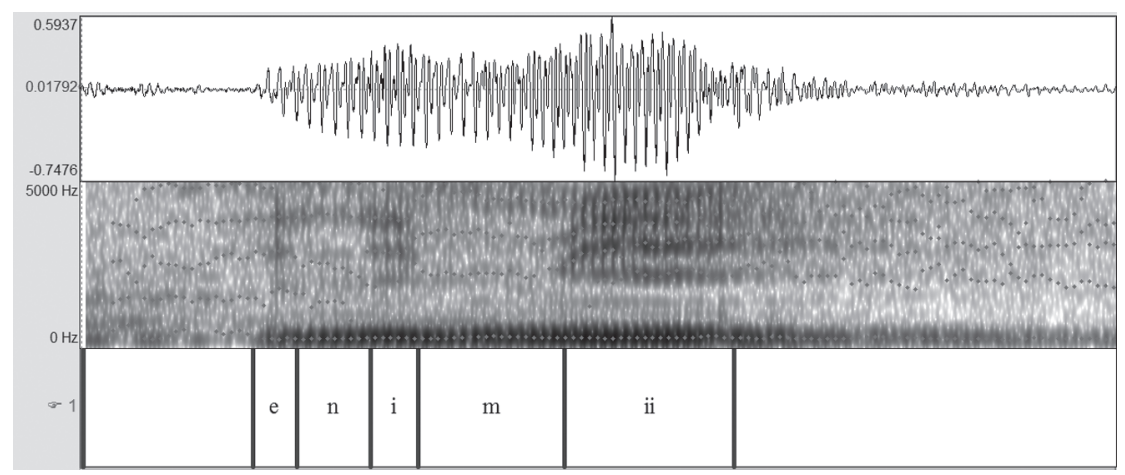

Figure 1c. A spectrogram of the form ènìmíyá [ènìmíi] from (4c)

noun stem if $\mathrm{W} \partial$ and $\mathrm{Y} \partial$ classes make a number correlation for a given noun (cf. the example cited here nìmí-wá 'needle, sg' ̀̀-nìmí-yá 'needles, pl'), but for other nouns only the relevant form was taken. No broader context other than the shape of the final part was taken into account.

The data with consistent separate pronunciations of full vs. reduced variants of the same form that were elicited three or more times were collected from a single speaker (a male in his late fifties). The recordings were made with the Marantz PMD-660 professional digital recorder and an external microphone $\mathrm{AKG} 1000$ in the .wav format (sampling rate $48 \mathrm{kHz}$, pulse-code modulation $16 \mathrm{bit}$ ).

For the instrumental study only a sample of the data was taken. Some types of final parts were excluded, since there was not a representative amount of data for them, while for some types of final parts only a part of data was used in order to make the sample more balanced. Table 3 presents the data, including nouns used, types of final parts and the number of analyzed instances of full and reduced variants. 
Table 3

Data for the instrumental study

\begin{tabular}{|c|c|c|c|c|c|c|}
\hline 苞莣 & 㺼 & $\stackrel{\varrho}{\Xi}$ & 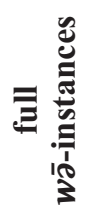 & 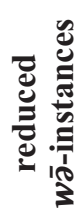 & 疍 & 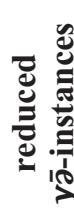 \\
\hline 1 & 2 & 3 & 4 & 5 & 6 & 7 \\
\hline \multirow[t]{4}{*}{ V } & $\mathrm{e}$ & $\begin{array}{l}s \bar{i} \bar{e}-w \bar{\partial} \text { 'food supply' } \\
\grave{e}-s \bar{i} \bar{e}-y \bar{\partial} \text { 'reserves of food' }\end{array}$ & 7 & 8 & 5 & 6 \\
\hline & $\mathrm{i}$ & 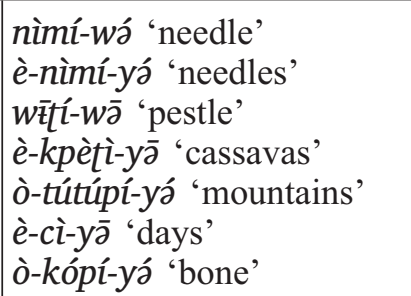 & 9 & 13 & 16 & 24 \\
\hline & I & $\begin{array}{l}t \bar{i}-w \bar{\partial} \text { 'anus (sg)' } \\
\grave{a}-t \bar{t}-y \bar{\partial} \text { 'anus (pl)' }\end{array}$ & 6 & 11 & 7 & 6 \\
\hline & $\partial$ & $\begin{array}{l}\text { nátá-wá 'noice' } \\
\text { nàtā-wā 'house' } \\
\text { à-nàtā-yā 'houses' } \\
\text { sáná-wá 'sheaf' } \\
\text { à-sáná-yá 'sheaves' } \\
\text { kpànā-wā 'river' } \\
\text { à-kpànā-yz̄ 'rivers' }\end{array}$ & 21 & 30 & 13 & 17 \\
\hline
\end{tabular}


Continuation of Table 3

\begin{tabular}{|c|c|c|c|c|c|c|}
\hline 1 & 2 & 3 & 4 & 5 & 6 & 7 \\
\hline & $\mathrm{u}$ & $\begin{array}{l}\text { tù-wā 'thing' } \\
\text { ò-tù-yā 'things' } \\
\text { tútú-wá 'chest' } \\
\text { kútúýkú-wá 'root' } \\
\text { ò-kútúýkú-yá 'roots' } \\
\text { témú-wá 'hammer' } \\
\text { è-témú-yá 'hammers' } \\
\text { ò-tū-yā 'stones' } \\
\text { ò-kú-yá 'beards' } \\
\text { ò-kú-yá 'rooms' } \\
\text { ò-kù-yà 'nests' }\end{array}$ & 15 & 18 & 34 & 31 \\
\hline & $U$ & 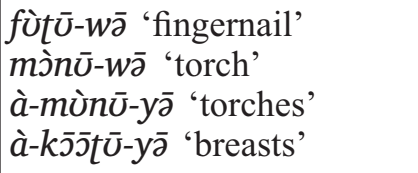 & 7 & 11 & 8 & 10 \\
\hline \multirow[t]{3}{*}{ VV } & aa & $\begin{array}{l}\text { náá-wá 'fire' } \\
\text { sínáá-wá 'rainbow' } \\
\text { à-sínáá-yá 'rainbows' } \\
\text { à-wáá-yá 'peels' } \\
\text { à-kpáà-yā 'granaries' }\end{array}$ & 11 & 10 & 10 & 14 \\
\hline & $\mathcal{E} \mathcal{E}$ & 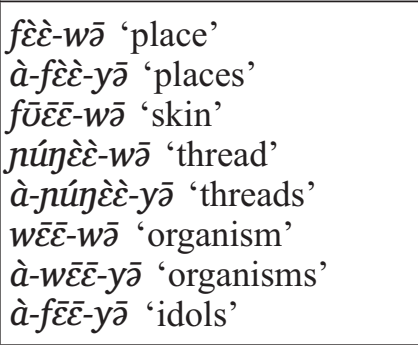 & 16 & 24 & 14 & 23 \\
\hline & oo & $\begin{array}{l}\text { kóó-wá 'umbilical cord' } \\
\text { ò-kóó-yá 'umbilical cords' } \\
\text { ò-kóó-yá 'kapok trees' } \\
\text { ò-kóó-yá 'navels' }\end{array}$ & 4 & 4 & 11 & 12 \\
\hline
\end{tabular}


End of Table 3

\begin{tabular}{|c|c|c|c|c|c|c|}
\hline 1 & 2 & 3 & 4 & 5 & 6 & 7 \\
\hline \multirow[t]{6}{*}{$\mathrm{Vy}$} & an & 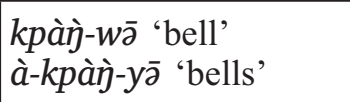 & 5 & 11 & 5 & 5 \\
\hline & $\varepsilon \eta$ & 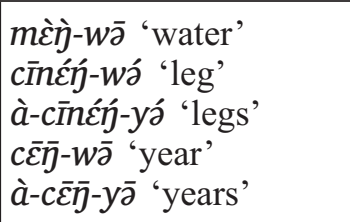 & 12 & 19 & 8 & 12 \\
\hline & in & $\begin{array}{l}\text { níý-wá ‘tip’ } \\
\text { è-níń-yá 'tips' }\end{array}$ & 6 & 9 & 5 & 6 \\
\hline & op & $\begin{array}{l}k \bar{o} \bar{\eta}-w \bar{\partial} \text { 'forest' } \\
\grave{o}-k \bar{o} \bar{\eta}-y \bar{\partial} \text { 'forests' }\end{array}$ & 6 & 5 & 5 & 6 \\
\hline & әџ & $\begin{array}{l}\text { wúlàỳ-wā 'granary' } \\
\text { ò-wúlà̀̀-yz̄ 'granaries' }\end{array}$ & 5 & 9 & 6 & 6 \\
\hline & un & $\begin{array}{l}\text { fūūy-wō 'hole' } \\
\text { ò-fū̄̄y } y \bar{\partial} \text { 'holes' }\end{array}$ & 5 & 5 & 4 & 4 \\
\hline
\end{tabular}

Formant measurements were carried out in the Praat ${ }^{7}$ software by Paul Boersma and David Weenink. ${ }^{8}$ Segmenting in Praat was not an evident task in this case, since it is not clear how the reduced variant should be segmented. This is why in reduced forms the entire final part and what follows it was segmented for the formant measurement as a whole. In contrast, in full forms, it was only the final part of the stem that was segmented, and the class suffix was not included. Figures $2 \mathrm{a}-2 \mathrm{~b}$ exemplify this way of segmenting for the noun náá-wá 'fire'. Figure 2a shows the segmented interval for formant measurement of the full variant where the initial consonant $n$ is left aside on the left and the class suffix -wa is left aside on the right. On Figure $2 b$ the relevant interval of the reduced variant is segmented where the initial

${ }^{7} \mathrm{http}: / /$ www.fon.hum.uva.nl/praat/

${ }^{8}$ Figures with acoustic graphs were made with Praat, as well. 
consonant is left aside on the left as well but nothing is left aside on the right. Thus, in full variants, the final parts of the stems were measured, and in reduced variants, clusters of the final parts of the stems and all the rest were measured. First, full vs. reduced variants were marked separately for each type of final part, and second, -wá vs. -yá forms were distinguished for each of them.

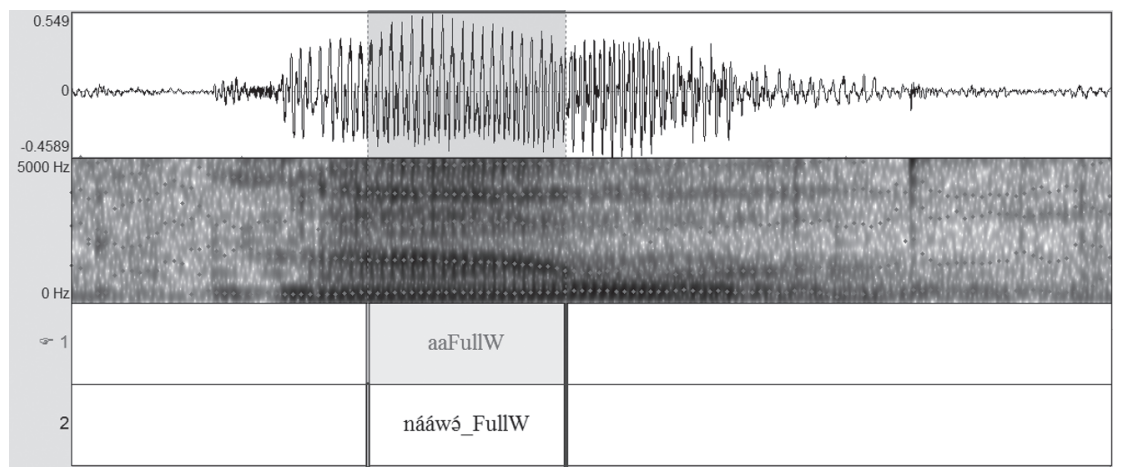

Figure 2a. Segmented interval for the full variant of náá-wá 'fire'

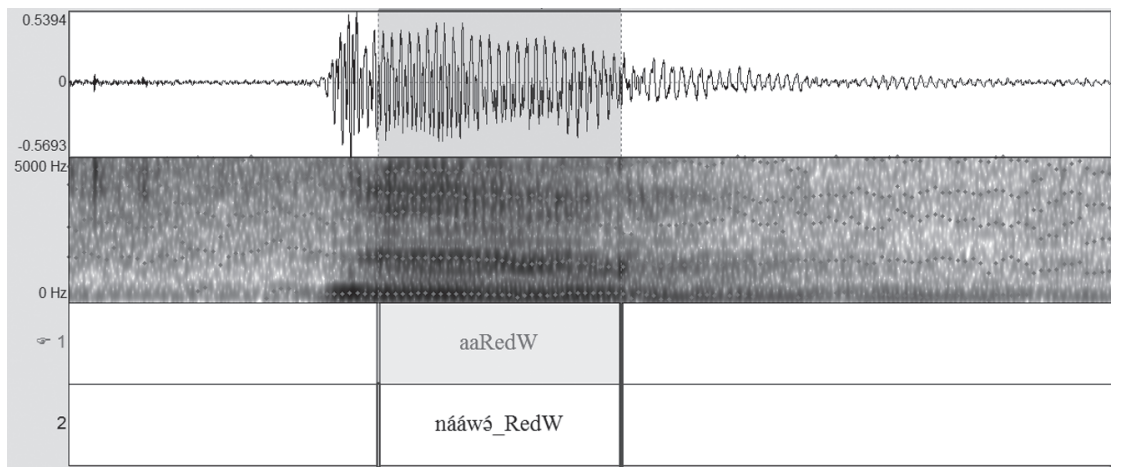

Figure 2b. Segmented interval for the reduced variant of náá-wá 'fire' 
The first two formants ${ }^{9}$ of the selected intervals were measured and analyzed using the corresponding script of the Speech Corpus Toolkit for Praat ${ }^{10}$ by Mietta Lennes. The results contain a number of artifacts of automatic measurements, since we are dealing with field recordings ${ }^{11}$, but are still clear.

\section{Results of the formant measurement study}

With a number of exceptions, the results of the formant measurements may be summarized as follows.

(i) F1 is not sensitive to the differences in the phonetic context both depending on the $w \bar{\partial}$-form vs. $y \bar{\partial}$-form and on the full vs. reduced variant. The values of F1 for the same type of final part either do not differ significantly between the contexts in focus, or differ arbitrarily.

(ii) F2 values of full and reduced variants of $w \bar{z}$-forms, on the one hand, are significantly closer to one another than F2 values of full and reduced variants of $y \bar{\partial}$-forms of the same type of final part, on the other hand. When contrasting a full $y \bar{\partial}$-variant and a reduced $y \bar{\partial}$-variant with the same final part with one another, the values of F2 either do not differ significantly, or differ arbitrarily, but in the latter case this difference is significantly less than the difference of the two and the $w \bar{z}$-forms with the same final part. The same is true for contrasting a full $y \bar{\partial}$-variant with a reduced $y \bar{\partial}$-variant with the same final part.

(iii) For a given final part, the F2 of $y \bar{\partial}$-forms is higher than the F2 of $w \bar{\partial}$-forms.

${ }^{9}$ Presumably, analyzing F3 might be also useful, since labialization is definitely one of the relevant features. Still, this study did not include this.

${ }^{10} \mathrm{https} / / /$ lennes.github.io/spect/, the script collect_formant_data_from_files. praat.

${ }^{11}$ I should also note that I used default parameters of the Praat script. Optimizing parameters might be also useful to get more fine-grained results. 
For some final parts, these generalizations can be inferred from a simple visualization of the formant space. For example, Figure 3a presents the formant space of a final parts. As one can see, final parts of full and reduced $w \bar{\partial}$-forms take the same place, as well as final parts of full and reduced $y \bar{\partial}$-forms. In $w \bar{\partial}$-forms, values of F1 exhibit significant variation, but this variation is present both in pronunciations of full and reduced variants. For other final parts, visualization is not so clear; see Figure $3 \mathrm{~b}$ with the formant space of $u$ final parts. The following labels are used for Figures 3: Full - full variants, Red reduced variants, $\mathrm{W}-w \bar{\partial}$-forms, $\mathrm{Y}-y \bar{\partial}$-forms.

Still, a more consistent picture can be seen if one compares the medians of the final parts in focus. Table 4 presents the results of the formant measurements. For each type of final part, median values of $\mathrm{F} 1$ and F2 are given for full and reduced variants of $w \bar{\partial}$-forms and of $y \bar{\partial}$-forms.

A grey background marks the results that do not fit into my generalizations. Namely, in $y \bar{\partial}$-forms of $U$ final parts and of $o o$ final parts and in $w \bar{\partial}$-forms of $e$ final parts and in final parts the difference in F2 between full and reduced variants is more significant than the difference in F2 between $w \bar{\partial}$-forms and $y \bar{\partial}$-forms. In in final parts this inconsistency with the general trend looks especially surprising, since in full variants of $w \bar{z}$-forms, in contrast to the reduced variants of $w \bar{z}$ forms, F2 shows no significant difference with ȳ̄-forms. With un final parts, the general trend is broken, since, according to the results of measurements, F2 of $y \bar{\partial}$-forms is lower, not higher, than F2 of $w \bar{\partial}$ forms. These exceptional results were not yet studied in detail, since the results of measurements of significantly more final parts can be reasonably generalized, and also, importantly, all these deviant final parts are those for which I have had a chance to use a relatively little sample of instances (see Table 3). 


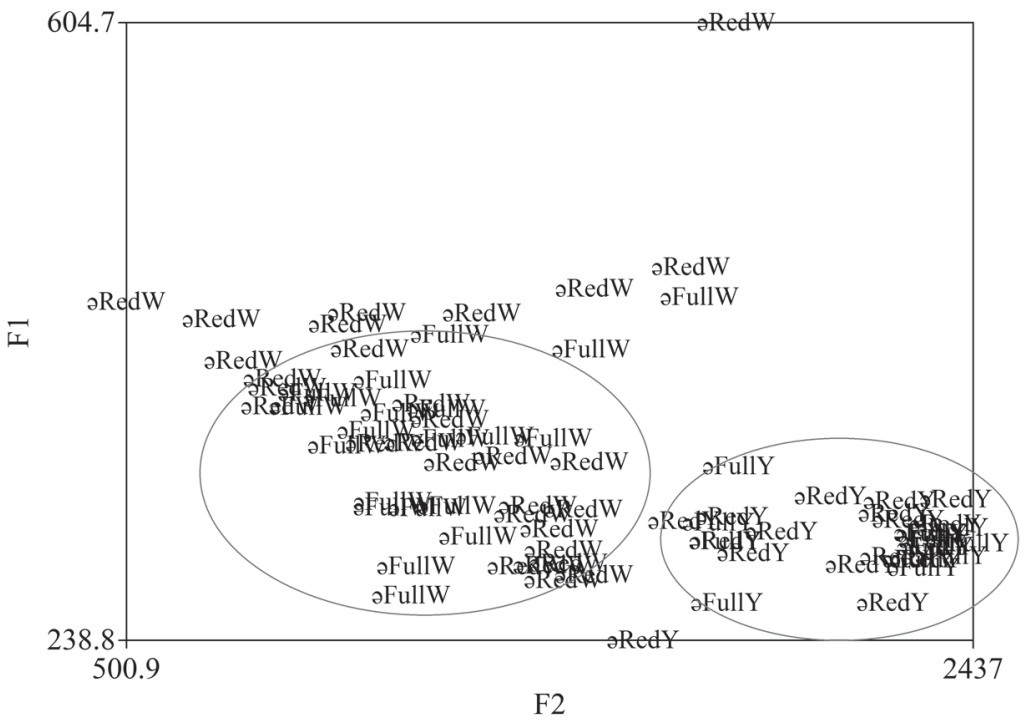

Figure 3a. Formant space of a-final parts

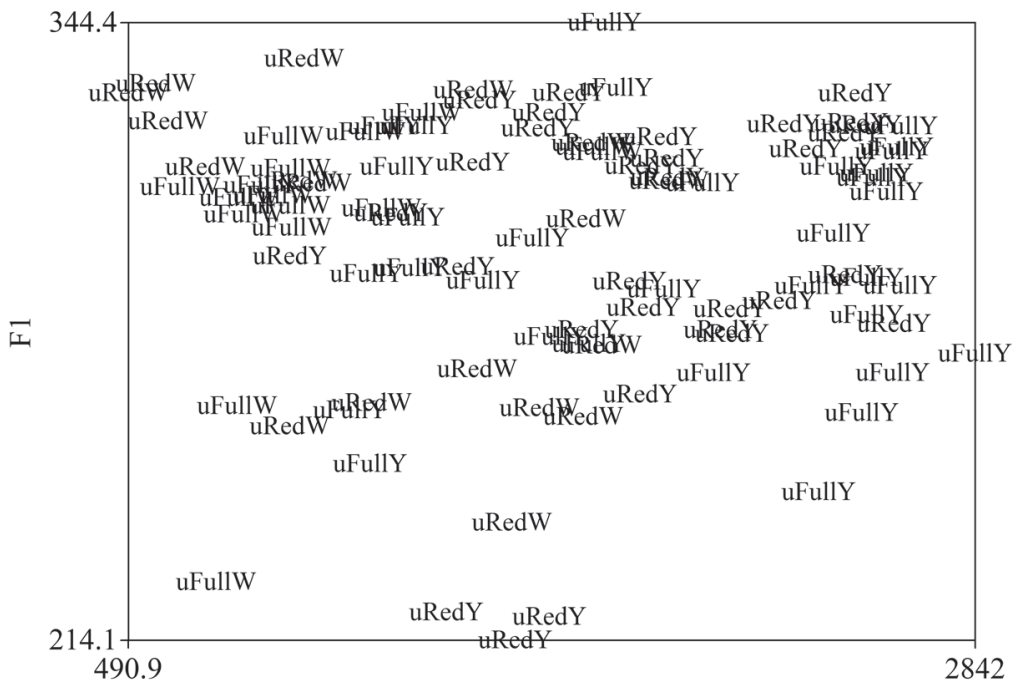

F2

Figure $3 \mathrm{~b}$. Formant space of $u$-final parts 
Table 4

Results of the instrumental study: medians of F1 and F2

\begin{tabular}{|c|c|c|c|c|c|c|}
\hline 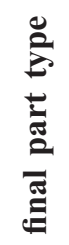 & 咅 & 葛 & 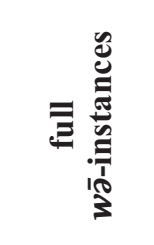 & 总 & 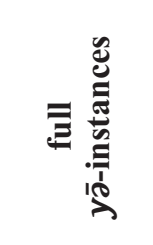 & 总 \\
\hline 1 & 2 & 3 & 4 & 5 & 6 & 7 \\
\hline \multirow[t]{12}{*}{$\mathrm{V}$} & \multirow{2}{*}{ e } & F1 & 348.7713 & 348.1015 & 346.8178 & 344.4121 \\
\hline & & F2 & 1434.026 & 1853.56 & 2060.53 & 2113.862 \\
\hline & \multirow{2}{*}{$\mathrm{i}$} & $\mathrm{F} 1$ & 296.4684 & 310.8154 & 274.3806 & 292.8168 \\
\hline & & $\mathrm{F} 2$ & 1630.918 & 1834.025 & 2369.672 & 2332.011 \\
\hline & \multirow{2}{*}{ I } & F1 & 315.2568 & 318.7781 & 288.3177 & 282.8604 \\
\hline & & $\mathrm{F} 2$ & 1615.173 & 1444.734 & 2297.773 & 2294.161 \\
\hline & \multirow{2}{*}{ ə } & F1 & 359.4484 & 362.6308 & 296.1102 & 305.3199 \\
\hline & & F2 & 1163.06 & 1349.329 & 2338.617 & 2253.464 \\
\hline & \multirow{2}{*}{$\mathrm{u}$} & F1 & 307.9259 & 310.6951 & 295.73 & 304.1806 \\
\hline & & $\mathrm{F} 2$ & 940.5907 & 1307.364 & 2101.048 & 1921.213 \\
\hline & \multirow{2}{*}{$U$} & F1 & 382.8997 & 333.3436 & 318.7777 & 319.2271 \\
\hline & & $\mathrm{F} 2$ & 1172.456 & 1189.394 & 1447.107 & 1817.273 \\
\hline \multirow[t]{6}{*}{$\mathrm{VV}$} & \multirow{2}{*}{ aа } & $\mathrm{F} 1$ & 353.0792 & 317.4924 & 442.6371 & 480.8067 \\
\hline & & F2 & 1318.356 & 1392.262 & 1590.047 & 1437.083 \\
\hline & \multirow{2}{*}{$\varepsilon \varepsilon$} & F1 & 361.3303 & 342.9098 & 318.3572 & 398.374 \\
\hline & & $\mathrm{F} 2$ & 1582.563 & 1523.026 & 1698.633 & 1739.592 \\
\hline & \multirow{2}{*}{ oo } & F1 & 347.8882 & 353.4693 & 348.7694 & 357.6632 \\
\hline & & $\mathrm{F} 2$ & 770.0188 & 838.2427 & 1077.306 & 1384.142 \\
\hline
\end{tabular}


End of Table 4

\begin{tabular}{|c|c|c|c|c|c|c|}
\hline 1 & 2 & 3 & 4 & 5 & 6 & 7 \\
\hline \multirow[t]{12}{*}{$\mathrm{Vy}$} & \multirow{2}{*}{ an } & F1 & 472.1083 & 515.3945 & 443.5603 & 497.3767 \\
\hline & & $\mathrm{F} 2$ & 1349.928 & 1277.198 & 1599.546 & 1690.896 \\
\hline & \multirow{2}{*}{$\varepsilon \eta$} & F1 & 342.3566 & 333.9937 & 323.6503 & 319.5483 \\
\hline & & $\mathrm{F} 2$ & 1404.918 & 1434.004 & 2005.735 & 2042.164 \\
\hline & \multirow{2}{*}{ in } & $\mathrm{F} 1$ & 250.2974 & 258.5414 & 268.7061 & 263.9958 \\
\hline & & $\mathrm{F} 2$ & 2416.899 & 1387.028 & 2428.704 & 2342.375 \\
\hline & \multirow{2}{*}{ on } & F1 & 317.3254 & 315.9218 & 351.6932 & 305.3037 \\
\hline & & $\mathrm{F} 2$ & 1072.193 & 1088.57 & 1161.408 & 1208.836 \\
\hline & \multirow{2}{*}{ ə⿹ } & $\mathrm{F} 1$ & 297.1728 & 317.646 & 302.3172 & 272.5201 \\
\hline & & $\mathrm{F} 2$ & 1390.888 & 1351.389 & 1631.101 & 1671.961 \\
\hline & \multirow{2}{*}{ un } & $\mathrm{F} 1$ & 323.3818 & 316.1648 & 320.4765 & 322.9931 \\
\hline & & $\mathrm{F} 2$ & 1944.864 & 1995.249 & 1120.419 & 1468.478 \\
\hline
\end{tabular}

\section{Discussion and conclusion}

The fact that there is a clear trend that the F2 of $y \bar{\partial}$-forms is significantly (and sometimes even radically) higher than the F2 of $w \bar{z}$-forms and the fact that there is no trend for F1 have a straightforward explanation. The articulation of $y$ and $w$ is very close to the articulation of the close front vowel [i] and of the close back vowel [u] respectively. As is well known (see e.g. Ladefoged 2001: 39-46), the feature of vowel height correlates with $\mathrm{F} 1$, and since $[\mathrm{i}]$ and $[\mathrm{u}]$ are both close vowels, no difference in F1 is expected. The feature of vowel backness correlates with F2, and since [i] and [u] are completely distinct in this feature, a very significant contrast in F2 is expected. Although in full variants only the final part of the stem was the interval where the formants were measured, a coarticulation effect gives such a significant difference on the F2 of the final part. Reduced variants retain the same coarticulation effect. For the noun stems with final parts that have no 
significant distinction in F2 between full and reduced variants (e.g. the $\varepsilon \eta$ final part with both forms), one can say that their reduced values contain no class marker acoustically (either do not have it at all or contain only vowel lengthening), but the coarticulation is retained exactly in the same form as in full variants. However, since with some final parts full and reduced variants of the same form still have a significant difference in F2, a more detailed acoustic analysis would be needed for a detailed description of the phonetic process in focus.

The most important result for phonological and morphological analysis of the reduced variants consists in the fact that reduced variants of $y \bar{\partial}$-forms always differ significantly from $w \bar{z}$-forms with the same type of final part for all final parts. In particular, this means that audial impressions where $V V$ final parts are perceived as [VV] (i.e. where the class suffix is perceived to be reduced to zero) are not completely correct. For example, although my audial impressions of the phonetic

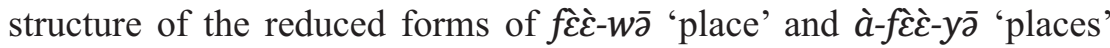
were [f๕̇̀े] and [àfè̀] respectively, with no difference (except for the initial class prefix), the instrumental study has shown that these final parts have a significant difference in F2 and thus are acoustically and therefore phonologically different. ${ }^{12}$ Additionally, this difference can be proven by lip movement. I have not conducted a systematic study of lip movement, but video recordings were done for a number of pronunciations of reduced variants of $y \bar{\partial}$-forms and $w \bar{z}$-forms. At the end of the pronunciation of a reduced $w \bar{\partial}$-form, the lips are rounded, while at the end of the pronunciation of a reduced $y \bar{\partial}$-form they are not. For example, Figure 4a presents a freeze frame of the end of a lips movement video recording of the reduced variant of kóó-wá 'umbilical cord', and shows rounded lips. Figure $4 \mathrm{~b}$ presents the same for the reduced variant of ò-kóó-yá 'umbilical cords', and the lips are not rounded. Figures $5 \mathrm{a}-5 \mathrm{~b}$ show the waveforms and the spectrograms of the same pronunciations.

${ }^{12}$ Still, importantly the difference in F2 is relatively small with $a a$ final parts and $\mathcal{E} \mathcal{E}$ final parts. 


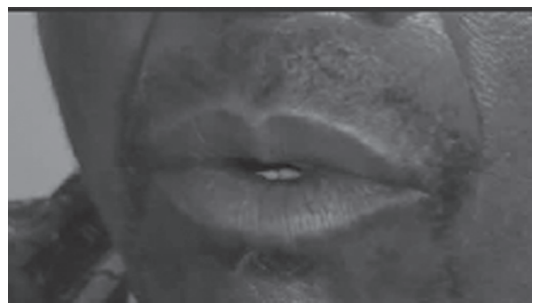

Figure 4a. Lips movement at the end of the reduced form of kóó-wá 'umbilical cord'

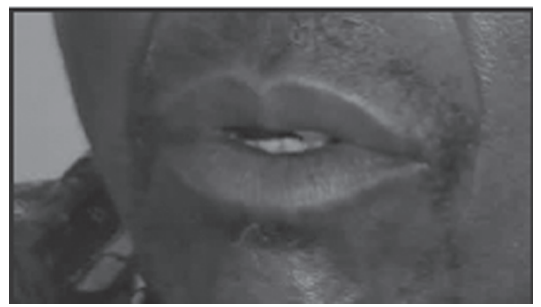

Figure $4 \mathrm{~b}$. Lips movement at the end of the reduced form of ò-kóó-yá 'umbilical cords'

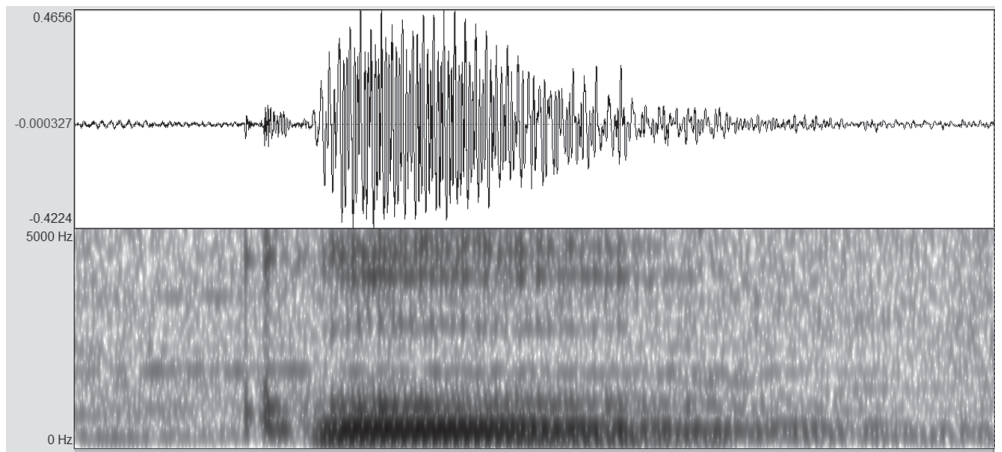

Figure 5a. Wave form and spectrogram of the reduced form of kóó-wá 'umbilical cord'

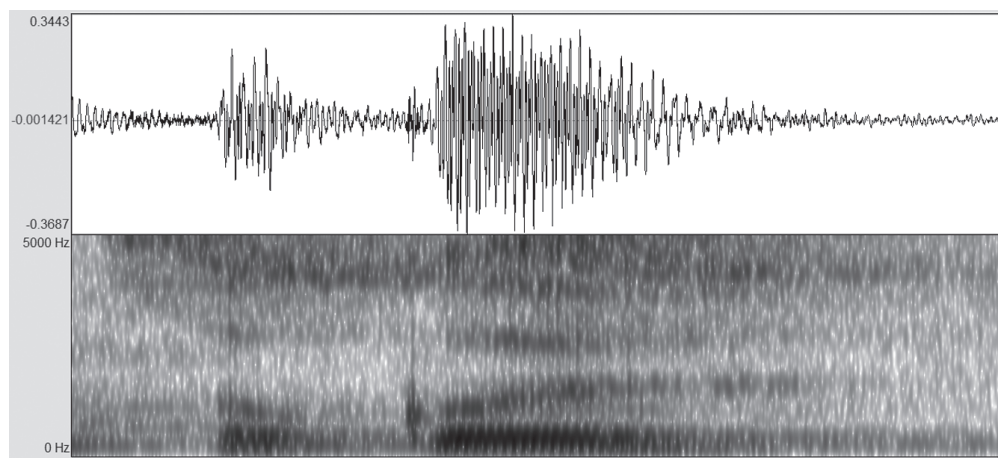

Figure $5 \mathrm{~b}$. Wave form and spectrogram of the reduced form of ò-kóó-yá 'umbilical cords' 
This study has shown that, first, for a given final part of a noun stem the reduced variant is phonetically close to the corresponding full variant and, second, for a given final part of a noun stem the reduced $w \bar{\partial}$-form is phonetically different from the corresponding $y \bar{\partial}$-form. Given the fact that by now we have no evidence that the use of reduced variants is linguistically or sociolinguistically restricted and that speakers tend to present reduced variants as negligent options for the corresponding variants, I have made the decision to treat the process in focus as a purely phonetical one and to only use the full forms in the phonological transcription. Therefore, apart from the syntactically driven contexts of the class suffix omission presented in 1.3, the nouns of the $\mathrm{DJ}, \mathrm{Y} \partial$ and $\mathrm{W} \partial$ noun classes are analyzed as always containing class suffixes in their morphology.

Apart from the pilot status of the phonetic side of this study, the following general question remains. A purely phonetical process is not expected to be driven by a purely morphological context, but here we have dealt with a reduction of specifix suffixes. Still, so far no other cases of word-final $-w \bar{\partial}$ and $-y \bar{\partial}$ are attested in the data, and thus as a tentative descriptive solution the process may be analyzed as driven only by the relevant phonological context. Therefore, a practical result of this study consists in the fact that the process of reduction of noun class suffixes that is the topic of this paper should be called more precisely the process of reduction of word-final $-w \bar{z}$ and $-y \bar{\partial}$.

\section{Acknowledgements}

The research was conducted in terms of the project supported by Russian Science Foundation, grant No. 17-78-20071 fulfilled in the Institute of Linguistics, Russian Academy of Sciences.

I express my sincere gratitude to the community of Akebu speakers in the villages of Djon and Kotora for our possibility to conduct a fruitful field research there in 2012, 2013, 2016 and 2019 and especially to Yao Lolonyo Akossu from whom the data used in this study were recorded. Ablavi Nata (Nathalie) Degblo, Sena-Kwami 
Sentibili, Kokou Mawuwodo (Honoré) Kokoroko and Yaovi Modeste Tchitche helped us a lot in organizing our stay and work. Our stays in Togo and trips inside the country became possible due to great efforts of Svetlana Roubailo-Koudolo.

I am grateful to Nadezhda Makeeva who is my close collaborator in Akebu studies, and Dasha Shavarina who also participated in Akebu field trips; both of them read and commented earlier versions of the paper. I also thank the anonymous reviewers, the audience of the linguistic panel of the $14^{\text {th }}$ Africanists Conference (Moscow, October 17-20, 2017) and other colleagues with whom I have discussed this study, especially Maria Konoshenko.

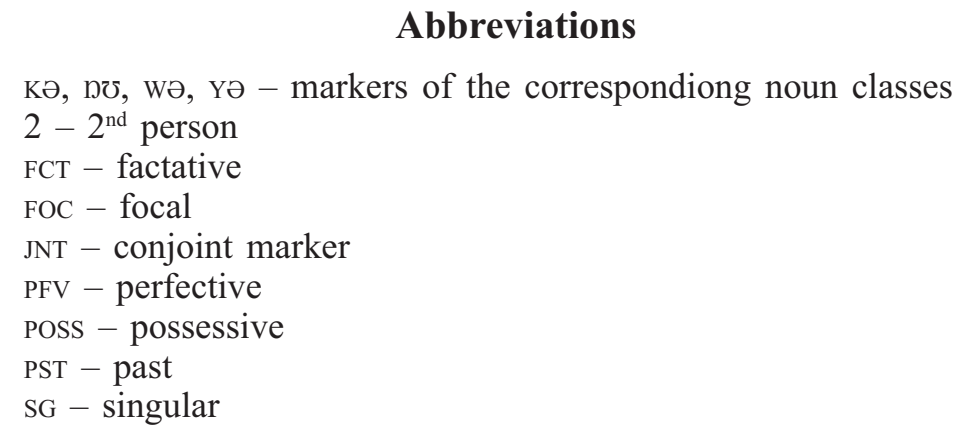

\section{References}

Amoua, Kwamivi. 2011. Le système nominal du kebu. Lomé: Université de Lomé. (Maîtrise.)

Djitovi, Afi. 2003. English and Akebu phonologies: A comparative analysis. Lomé: Université de Lomé. (Maîtrise.)

Eberhard, David M. \& Simons, Gary F. \& Fennig, Charles D. (eds.). 2019. Ethnologue: Languages of the World, $22^{\text {nd }}$ ed. Dallas, Texas: SIL International. Online version: http://www.ethnologue.com.

Gblem-Poidi, Honorine Massanvi \& Kantchoa, Laré. 2012. Les langues du Togo: État de la recherche et perspectives. Paris: L'Harmattan.

Heine, Bernd. 1968. Die Verbreitung und Gliederung der Togorestsprachen. Köln: Dietrich Reimer Verlag. 
Konoshenko, Maria \& Shavarina, Dasha. 2019. A microtypological survey of noun classes in Kwa. Journal of African Languages and Linguistics 40(1). 75-114.

Ladefoged, Peter. 2001. Vowels and consonants: An introduction to the sounds of languages. Oxford: Blackwell.

M'boma, Komlavi Malanbo. 2012. Précis d'écriture de la langue akébou dans le sillage de la construction linguistique. Monroe, Louisiana: Evangel Christian university. (Ph.D. dissertation.)

Makeeva, Nadezhda. 2013. Fonologičeskaja sistema jazyka Akebu [Phonological system of Akebu]. In Devjatkina, Ekaterina et al. (eds.), Problemy jazyka, 262-276. Moscow: Institut jazykoznanija RAN.

Makeeva, Nadezhda. 2016. Fonotaktika jazyka akebu [Phonotactics of Akebu]. In Devjatkina, Ekaterina et al. (eds.), Problemy jazyka, 199211. Moscow: Institut jazykoznanija RAN.

Makeeva, Nadezhda \& Shluinsky, Andrey. 2015. Imennye klassy i soglasovanie v jazyke akebu. In Vinogradov, Viktor et al. (eds.), Issledovanija po jazykam Afriki 5, 174-200. Moscow: Ključ-S.

Makeeva, Nadezhda \& Shluinsky, Andrey. 2018. Noun classes and class agreement in Akebu. Journal of West African languages 45(1). 1-26.

Sossoukpe, Jacques. 2017. Effet voisant du ton bas flottant sur les obstruantes en akebou. In Ahoua, Firmin \& Elugbe, Benjamin Ohi (eds.), Typologie et documentation des langues en Afrique de l'Ouest. Les actes du $27^{\mathrm{eme}}$ Congrès de la société de linguistique de l'Afrique de 1'Ouest (SLAO), 139-146. Paris: L'Harmattan.

Sossoukpe, Marthe. 2014. Guide pour aider les scolarisés en français à lire et écrire l'akébou. Lomé: SIL Togo.

Storch, Anne \& Koffi, Yao. 2000. Noun Classes and Consonant Alternation in Akebu (Kàgbə̀rə̄kó). In Meissner, Antje \& Storch, Anne (eds.), Frankfurter Afrikanistische Blätter 12. Nominal classification in African languages, 79-98. Köln: Rüdiger Köppe Verlag.

Wolf, Franz. 1907. Grammatik des Kögbörikö (Togo). Anthropos 2. 422$437,795-820$. 